\title{
Bridging different perspectives for biocultural conservation: art-based participatory research on native maize conservation in two indigenous farming communities in Oaxaca, Mexico
}

\author{
Flor Rivera López ${ }^{1,2} \mathbb{D} \cdot$ Fern Wickson ${ }^{1} \cdot$ Vera Helen Hausner $^{2}$
}

Received: 27 September 2018 / Accepted: 21 November 2019 / Published online: 21 December 2019

(C) The Author(s) 2019

\begin{abstract}
Native maize conservation rests on the custody of traditional and indigenous small-scale farmers, but their traditional practices and way of life are challenged by multiple forces associated with globalization, international trade and neoliberal agricultural policies. Through participatory art-based research with two indigenous communities in Oaxaca, Mexico, we identified the main challenges and strategies for native maize conservation, as perceived by these farming communities. We implemented a stepwise method to elicit local strategies for biocultural conservation pertinent across gender and generations. We conclude that understanding the heterogeneity of perspectives is important for identifying root causes of agrobiodiversity decline and strategies for biocultural native maize conservation.
\end{abstract}

Keywords Biodiversity $\cdot$ Art-based research $\cdot$ Participatory methods $\cdot$ Biocultural conservation · Transdisciplinary

\section{Introduction}

Mexico is considered the centre of origin of maize (Zea mays) due to the presence of wild relatives Teocintle group (or teosinte) (Zea spp.) coexisting with domesticated maize varieties (Kato Yamakake et al. 2009). Due to the long history of domestication and cultivation, maize is fundamental for the economy and the cultural identity in Mexico (Barrera-Bassols et al. 2009). Maize not only represents the major staple food source but also occupies more than a half of the total planted area in Mexico (Appendini 2014). More than 40\% of the total farm labour force in Mexico is dedicated to maize farming, which is predominantly performed by small-scale farmers (De Ita 2007; Nadal and Wise 2004). In Mexico, native maize seeds are primarily cultivated by traditional and indigenous small-scale farmers in rainfed-dependent areas. This means traditional and indigenous small-scale farmers are

Flor Rivera López

flor.r.lopez@uit.no

1 Genøk Center for Biosafety, Siva Innovasjonssenter, PB 6418, 9294 Tromsö, Norway

2 UiT The Arctic University of Norway, PB 6050, 9037 Langnes, Tromsö, Norway 
also the custodians of native maize biodiversity. Maize farming and the conservation of the biodiversity of native varieties have, however, been significantly affected by changing Mexican policies over recent years (Appendini and Liverman 1994; Eakin et al. 2015). In the late 1980s and early 1990s, for example, Mexican agricultural polices went from being protectionist towards opening up for commercial farming and international trade (Sweeney et al. 2013). In 1994, the North American Trade Agreement (NAFTA) was signed by Mexico and subsequently large commercial farmers that could efficiently compete in the international market were favoured by state support. The small-scale farmers, who historically created and maintained agrobiodiversity, therefore saw their previous access to state subsidies and credits decrease (Sweeney et al. 2013). In addition, CONASUPO (the national institute in charge of regulating grain trade and assuring a market for small-scale maize farmers) was dissolved in 1998, leaving small-scale farmers unprotected against competition from large-scale commercial farming (Eakin et al. 2015). To be competitive and access governmental support, some small-scale farmers changed their traditional farming system to that of the modern model of industrialized agriculture by planting high-yielding hybrid seeds in monocultures dependent on agrochemicals (Pérez-García and del Castillo 2016). The farmers who remained small scale not only faced new competition from larger-scale growers, but also had to deal with serious droughts. This provoked continuous losses for farmers whose plots were primarily rainfed and brought bankruptcy to thousands of farmers (Eakin et al. 2015). Many farmers migrated and abandoned their land during this time to look for other ways to generate their families' livelihoods. This movement of traditional and indigenous farmers off the land was to the detriment of the in situ or 'on-farm' conservation of the biodiversity of native seeds (Robson and Berkes 2011a).

Surprisingly, despite the challenges and adversity that has pushed thousands of farmers to abandon their land and traditional maize farming practices (including policies that have encouraged the substitution of native seeds by hybrids as promoted during the green revolution) native maize farming has persisted and is still of great importance in Mexico (Becerril and Abdulai 2010). Appendini and Quijada (2016) argue that this phenomenon can be explained by the multiple purposes served by native maize in Mexico. Native maize provides food security and nutrition, but there is also a culinary preference for native varieties since they are said to taste better and make better tortillas and other maize dishes, and a cultural significance as they are also used in festivities and ceremonies. Thus, the selection and maintenance of native maize biodiversity is based not only on agronomic, economic and ecological considerations, but also on culinary, cultural and even ritual-based aspects (Tuxill et al. 2010). Consequently, a diversity of landraces of native maize has arisen in Mexico not only in relation to the diversity of climates, soils and altitudes where maize is grown, but also significantly in relation to the diversity of cultural and culinary uses the crop has across different communities (Aragón-Cuevas et al. 2006). Maize farmers do not always necessarily recognize themselves as guardians of agrobiodiversity. However, through their practices as small-scale food producers in Mexico, they play a globally important role as custodians of the seeds and keepers of cultural heritage, primarily by working as active developers and conservers of maize biodiversity (Barrera-Bassols et al. 2009; Boege and Chan 2008).

The interrelation between biological and cultural diversity is increasingly recognized as fundamental for biodiversity conservation (Bennett 2016; Posey 1999). The biocultural heritage of indigenous food production was also recently on the agenda of the UN Permanent Forum on Indigenous Issues (Swiderska and Argumedo 2006), which emphasized the need to support custodian farmers to preserve crop diversity. Biocultural heritage has been defined by Gavin et al. (2015) as the 'knowledge, innovations, and practices 
of indigenous and local communities that are collectively held and inextricably linked to, and shaped by, the socioecological context of communities'. The indigenous biocultural heritage approach (IBCH) looks upon indigenous communities as local custodians of agrobiodiversity, emphasizing the need to safeguard cultural practices of food production to halt loss of native crop varieties plants (Graddy 2013). Causes of loss in agrobiodiversity are accordingly dependent on intergenerational transmissions of knowledge, practices and beliefs, and the social, cultural, economic and political factors influencing cultures in the communities (Davidson-Hunt et al. 2012).

Participatory research that creates collaborations among researchers, farmers and indigenous peoples can help to decrease power imbalances between researchers and participants, reduce scepticism towards researchers and encourage more reflexive, respectful and culturally sensitive research practices (Flicker et al. 2007; Hoffmann et al. 2007; Minkler 2004). Participatory agroecological research where science works with and for indigenous communities to identify challenges and conservation strategies has previously resulted in social transformations benefiting both farmers and biodiversity conservation (Mendez et al. 2013; Rosset et al. 2011). However, participatory research methodologies vary considerably in their potential to stimulate creative thinking and innovations among community members. Moreover, participatory research has been criticized for sometimes ignoring heterogeneity and inequalities, thereby contributing to the marginalization of those with less voice and power in communities (Minkler 2004). Assuring inclusionary processes with diverse members in the community while curtailing the influence of researchers needs careful consideration early in the planning phase of a participatory project (Long et al. 2016).

In the past, collaborations between farmers and researchers directed towards native maize conservation have often been focused on issues such as agronomic improvement and adaptation to land and climate change (Hellin et al. 2014; Lilja and Bellon 2008). Nevertheless, recent studies describe how social dimensions such as ethnicity (Brush and Perales 2007; Orozco-Ramírez et al. 2016), age (De St. Maurice and Miller 2017) and gender (Bee 2014; Bhattarai et al. 2015) or combinations of such factors such as age and gender (Bordi et al. 2016) or ethnicity and gender (Lau and Scales 2016) influence agrobiodiversity conservation. Furthermore, agrobiodiversity conservation has been recognized as a means for food sovereignty and respect for indigenous farmers' rights (Bezner Kerr 2013; Fitting 2011).

The purpose of our study was to identify the challenges and strategies for biocultural conservation perceived by different indigenous maize farming communities. Bennett (2016) defines perceptions as the way an individual observes, understands, interprets and evaluates a referent object, action, experience, individual, policy or outcome (Bennett 2016, p. 585). Perceptions depend on context and experiences, and the values, norms, beliefs, preferences, knowledge and motivations that are individually and collectively held in the community. Berkes (2009) argues that local perceptions need to be understood as knowledge developed locally, through interactions with their environment, and that they have been transferred across generations. Intergenerational transmission of knowledge about native maize farming between elders and the younger generation is important, but not sufficient for biocultural conservation.

Local perceptions of conservation challenges depend on sociocultural values and are shaped to a variable extent by interactions with NGOs, governmental agencies or media (Dove et al. 2009). For example, indigenous farmers could be aware of conservation issues, such as transgenes contaminating native landraces of maize (Bonneuil et al. 2014), but those cultivating the crops may perceive this issue as subordinate to the economic realities. Consequently, conservation could fail, as farmers may perceive the challenges differently 
than external initiatives that frame problems too narrowly. Negative experiences with previous conservation initiatives could also result in resistance, despite there being shared knowledge about the problem and agreement on the cause. To create positive change, the native farming communities must therefore be part of a process to define the relevant challenges and strategies to overcome them in a way that can be informed by their own perceptions. Local perceptions of challenges to biocultural conservation differ within and between communities. Understanding the heterogeneous perceptions of an issue is key to understand why some community members support some conservation initiatives and not others. Understanding and bridging these different local perceptions on conservation and make shared strategies for action that is supported across different age and gender groups is more likely to succeed in terms of conserving native maize. Adopting this theoretical framework emphasizing the value of understanding local perceptions of the problem and using a stepwise art-based design, we aimed to collect voices in an equitable and inclusive manner across different age and gender groups in two indigenous farming communities in Oaxaca.

We were interested not only in seeing and comparing potential differences across age, gender and community groups, but also in working across these differences to arrive at shared strategies for action. Art is highly integrated in the Oaxacan way of life and is important for expressing social, cultural and political issues in the communities (Carruthers 2001; De La Rosa and Schadl 2014; McCaughan 2006). Oaxacan art is therefore valuable for the intergenerational transmission of knowledge, practices and beliefs and thus also arguably for long-term biocultural conservation (Davidson-Hunt et al. 2012). We therefore employed art as part of our research method to help motivate people to reflect upon the past, present and future of native maize farming, to facilitate conversations and to stimulate creative thinking and deliberations over community members' feelings and their relationship to maize conservation. Our participatory art-based research design aimed to facilitate participants' reflections on their experienced realities regarding native maize farming, their contribution to this reality and their potential to create social change by encouraging a critical consciousness (Carlson et al. 2006; Freire 1970). Using art also helped participants share their thoughts about maize farming with a wider audience in or outside the community and thereby also strengthened the transformative potential of the participatory research by acting as a reflection catalyst in the community (Coemans and Hannes 2017). In what follows, we describe our participatory art-based research methods and our findings across the different age, gender and community groups. We then conclude our paper by discussing our findings in relation to existing literature and highlighting how art-based research methods implemented in a participatory stepwise fashion can promote equitable participation of a heterogeneous public, including women and young generations, with different roles and status in the communities. We particularly highlight the importance of exploring this heterogeneity of perspectives from gender, age and communitarian context for developing a broader understanding of the various elements involved in agrobiodiversity decline and identifying shared strategies for biocultural native maize conservation. 


\section{Location and methods}

\subsection{Location}

The study was conducted in two different indigenous communities of Oaxaca. There are 16 indigenous peoples living in the state of Oaxaca. In Mexico, the indigenous population is calculated mainly on the number of indigenous language speakers. Oaxaca holds the largest population of indigenous language speakers, representing approximately $19 \%$ of the indigenous population of the country (Ordonez and Rodríguez 2008; INEGI 2011). Oaxaca is also ranked as the most biodiverse state, with $40 \%$ of all plant species in Mexico present in the state (Ordonez and Rodríguez 2008; INEGI 2011). Oaxaca also has a rich agricultural diversity with farmers growing 35 different maize landraces, representing approximately $70 \%$ of the national richness of all landraces of maize (Aragón-Cuevas et al. 2006). In spite of its biocultural richness, Oaxaca is the third most marginalized state of Mexico (Ordonez and Rodríguez 2008) and one of the poorest states of the country, with $70.4 \%$ of the population living in poverty or extreme poverty (CONEVAL 2016). Historically, indigenous peoples have been discriminated and ignored in Mexico. Oaxaca being largely populated by indigenous peoples portrays the harsh reality indigenous people have had to face regarding their decision power and respect of their rights. Oaxaca also portrays the strength of indigenous movements to resist and fight for the improvement of their undesirable situation (López Bárcenas 2016). The biocultural richness and social complexity of Oaxaca represent an important reason for selecting the state for this study.

The biocultural richness of Oaxaca includes popular traditions such as Guelaguetza festival. This is a traditional festival where communities celebrate solidarity to overcome scarcity in a joyful way. Community solidarity and the strengthening of bonds for cooperation among farmers are crucial for maintaining native maize farming and for reducing dependency on external labour. Guelaguetza also asks the Gods for provision of sufficient rain and food. As in many festivals in Mexico, maize is an important element in the festivity. People honour the maize Goddess Centeotl with dances and paintings, and the foods shared in Guelaguetza are based on maize (Whitford 2008).

The two communities-Santiago Apostol in Central Valleys and Nuevo Santiago Tutla in Sierra Mixe-were chosen because they portray a diverse set of realities within Oaxacan indigenous communities growing maize (Fig. 1). It is important to highlight that both communities had previously been in contact with Oaxacan grassroots organizations participating in the National Network in Defense of Maize. This is a network that one of the authors has collaborated closely with over several years, which helped her to connect with the communities and establish a relationship of trust prior to the project beginning.

Santiago Apostol (Apostol) is a Zapotec indigenous community, located just 1-h drive from the capital city of Oaxaca. Despite this proximity, people in this community still speak the Zapoteco language and keep many of their cultural traditions. Festivities are very important in the community to strengthen community bonds. The celebration of 'Santo Patrono' Santiago and the Guelaguetza is the most important festivities and takes place at the end of July every year. Even though the land is private and not under a collective property regime such as ejido or collective community ownership (the most common property regimes in rural Oaxaca), decisions are still taken collectively within a communitarian assembly. The proximity to a major city centre and a significant level 


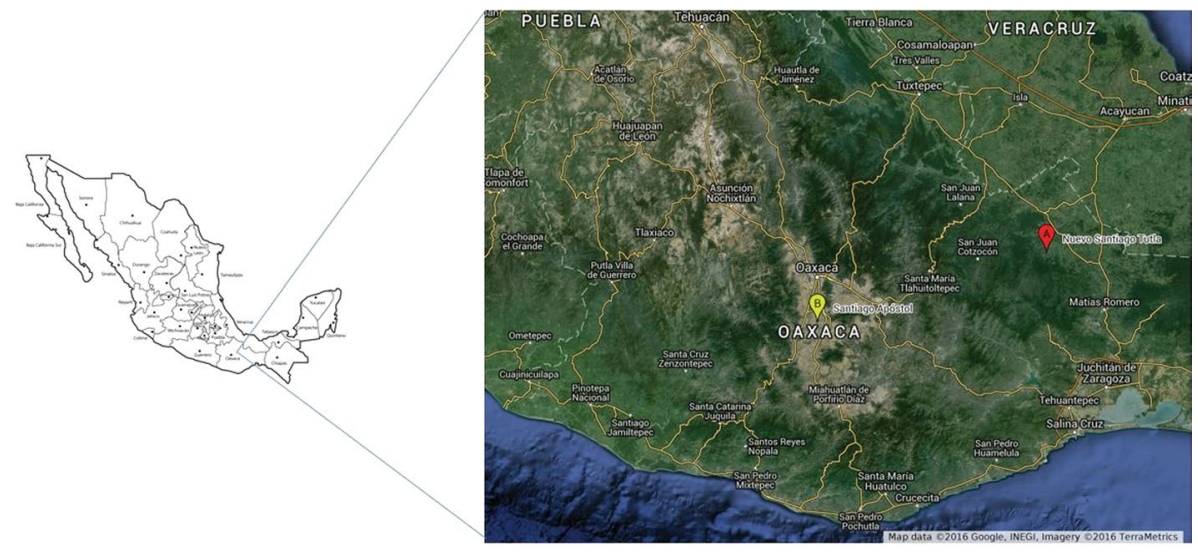

Fig. 1 Location of the study areas

of temporal and permanent emigration to the USA have created many cultural changes. Apostol has a stronger focus on 'for-profit' farming practices based on modern industrial systems and technological advances than in other more traditional native maze farming communities.

Nuevo Santiago Tutla (Tutla) is a Mixe people community located 8-h drive from the capital city and 2-h drive from the nearest urban area. In this community, Mixe is the official language and their traditions are still strongly rooted in native maize farming. Tutla, in contrast to Apostol, is under a collective community land property regime. Thus, nobody can claim individual property and/or control over the land as all decisions must be taken collectively in the communitarian assembly, which represents the highest authority. The emigration pattern is mainly temporary and national, mostly among young people, who usually return to the community after some time spent in cities nearby for study or temporary jobs.

\subsection{Methods}

To identify challenges and shared strategies for addressing them for native maize biodiversity conservation in a way that enabled comparison across different communities' context, age and gender groups, we designed a stepwise participatory research process that included an art-based component as a method to stimulate creative thinking and facilitate dialogue (Fig. 2).

\subsubsection{Step one: Communitarian meeting: project presentation and recruitment of participants}

The first step in the process was a general meeting with the community where we informed them about the research project and sought to recruit participants. The primary aim of the communitarian meeting was to start the dialogue about our project with community members and recruit a diverse set of participants. During the presentation of the project at this meeting, we discussed all questions related to the project, the researchers involved and the proposed art-based participatory approach. After receiving information about the 


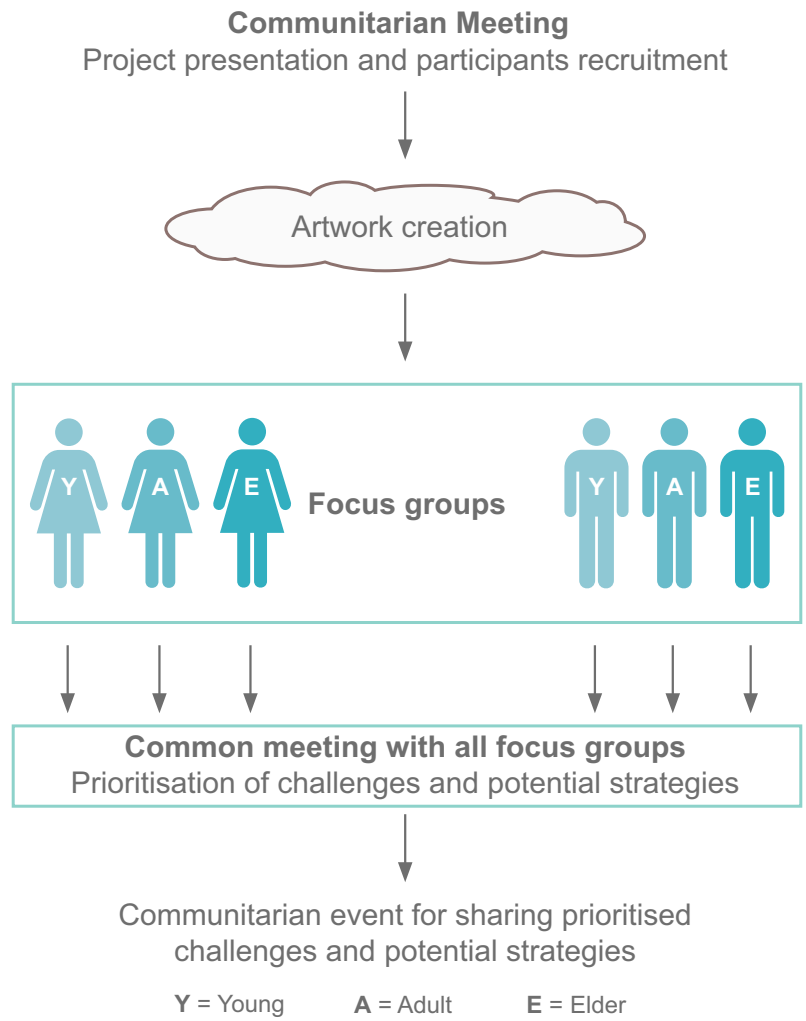

Fig. 2 Flow chart of participatory art-based method

project, participants from both communities who decided to voluntarily be part of the project signed a written consent form, indicating their willingness to be involved, including a signed approval from the legal guardians of any minors wishing to participate. All participants in Nuevo Santiago Tutla were Mixe indigenous people. In Santiago Apostol, the majority of the participants identified themselves as Zapotec indigenous people, but a few were also non-indigenous or mestizos.

\subsubsection{Step two: Artwork creation}

In step two of our research process, we adopted an art-based participatory research approach to help participants consider and discuss their ideas concerning the challenges and solutions in a way that was independent of their knowledge and status in the community (Coemans and Hannes 2017). For this, we developed a unique method that builds on and extends the Photovoice method (Wang and Burris 1997).

Our method, which we called 'CreativeVoice', is described in detail in Rivera Lopez et al. (2018). The method was based on the same principles as Photovoice but extended through allowing the use of a broader range of creative art-based approaches than just photography to encourage participants to express their own thoughts and feelings without too much interference from the researchers. Participants were permitted to choose the art form 
they felt most comfortable with to reflect upon the past, present and future of native maize farming. The idea was to raise 'critical consciousness' (see Freire 1970) by increasing participants' awareness of the challenges and solutions in order to build capacity to create positive change. For many indigenous communities, and especially in Oaxaca that has a rich cultural heritage relating to visual arts, stories, songs and poems, other art forms may be more suitable for expressing the emotional and cultural ties to the land. As the artworks were meant to stimulate creative thinking and open up the discussions about maize farming regardless of a participants' position in the community, we chose to extend the possibilities participants had to express themselves through art forms favoured within either their own cultural traditions and/or personal preferences. To provide some guidance, we listed three different categories of possibility: (1) drawing/painting, (2) photograph/videos and (3) stories/poems/songs. However, these categories were not exclusive and participants could select other art forms if they wished. Participants were asked to create an artwork portraying their own story related to the history of native maize in their community. Here, they were encouraged to use the creation of their artworks to particularly reflect on what they saw as challenges facing native maize conservation and how they wanted the future of native maize to look. Participants were given up to 5 weeks to create their artworks and were then invited to bring them to small focus group discussions.

\subsubsection{Step three: Focus group discussions}

In each of the two communities, we established six focus groups, which were divided by gender and age criteria. We had three age groups: Youth (12-25), Adults (25-50) and Elders $(50+)$, each of which was further divided into a male gender group and a female gender group. In the age/gender focus groups, participants presented their artworks and discussed their perceptions concerning the challenges facing maize biodiversity conservation in their community as captured and represented in their artworks. These sessions were audio- and video-recorded for later analysis. The specific purpose of the small focus group discussions was to identify the challenges specific to age and gender and to have these groups start to imagine potential strategies to address these challenges.

\subsubsection{Step four: Joint meeting with all focus groups: prioritization of challenges and potential solutions}

In step four of the research process, all project participants in the community gathered in a joint meeting to exchange and discuss the ideas that arose in the focus groups on the perceived challenges and strategies to address them. The groups were combined in a plenary session where we worked together to identify shared perceptions of challenges, agree on a prioritization of the challenges for that community and seek consensus on some feasible strategies that they could pursue to enhance native maize biodiversity conservation within their communities.

\subsubsection{Step five: Communitarian event for sharing the prioritized challenges and potential solutions}

Finally, we presented the artworks, challenges and potential solutions at a common communitarian event that included members of the community that did not directly participate in other parts of the process. This event aimed to stimulate a broader discussion of native 
maize conservation within the community and encourage involvement and support from those outside the project to participate in the commonly agreed strategies to promote positive change towards maize biodiversity conservation within the communities.

\section{Results}

\subsection{Participants' recruitment}

A total of 72 community members from three different generations joined our art-based participatory research project. This involved 31 participants (16 males, 15 females) from Apostol and 41 (18 males and 23 females) from Tutla (Table 1). It was challenging to recruit participants in the adult focus group in both communities, due to their busy agendas. As a result, in Apostol we were only able to recruit four adult male participants and only one participated in the focus group. Even though we faced difficulties to recruit adult participants and their participation in the focus groups was limited, particularly in Apostol, we were able to supplement our focus group work by collecting information on adult perspectives through informal interviews with individuals in both communities. These conversations were recorded (with consent) and included in the analysis presented below. The adults who decided to participate in the project in Apostol were those already interested in conserving maize biodiversity, while the large part of the community using non-native seeds (e.g. modern hybrids) and non-traditional and more commercial types of farming (e.g. using agrochemicals, tractors) did not choose to participate in our project. In other words, our results do not represent the whole range of perspectives existing within the community, but rather identify a range of diverse challenges and potential conservation strategies that members of the community interested in native maize conservation are concerned about and willing to work on.

\subsection{Creation of artworks}

The participants created a diversity of artworks including paintings, fairy tales, photographs, drawings, embroideries and a wall mural. Contrary to our expectations (and the offer to provide any necessary equipment), photographs and videos were the least popular art form, even among the young participants. This highlights the importance of expanding the Photovoice approach and including other forms of artistic expression beyond photography. Despite embroidery not being presented as an example of a type of art form that could be used, it was the most popular form of artistic expression, particularly among women,

Table 1 Number of participants by age and gender recruited in each community

\begin{tabular}{lrrrr}
\hline & \multicolumn{2}{c}{ Santiago Apostol } & & \multicolumn{2}{l}{$\begin{array}{l}\text { Nuevo Santiago } \\
\text { Tutla }\end{array}$} \\
\cline { 2 - 5 } & \multicolumn{1}{c}{} & & & \\
\cline { 2 - 5 } & 6 & 6 & 10 & 6 \\
Young & 4 & 4 & 6 & 6 \\
Adults & 5 & 6 & 7 & 6 \\
Elders & 15 & 16 & 23 & 18 \\
\hline
\end{tabular}


while male participants did not favour any particular form. Some participants decided to engage in the project and focus group discussions without creating an artwork. However, all were enthusiastic to talk about the artworks presented by other participants. We clearly saw that the artworks encouraged people to talk and share their knowledge, experiences and stories of native maize and contributed to a friendly and relaxed atmosphere during the focus group discussions. Images presented in drawings, embroideries, paintings and photographs proved to be powerful visual tools for triggering memories and reflections among the participants during the focus groups and the broader community meetings, helping members to recognize their history as portrayed in the artworks and to evaluate losses and gains as seen through historical changes in their communities over time (Rivera Lopez et al. 2018). In Apostol, the wall mural painted in the main street of the community stayed beyond the life of the project as a constant reminder of the important role played by native maize in their history and cultural identity, as well as the threats to conservation being posed by non-native seeds and industrialized agricultural systems (Fig. 3).

\subsection{Perceptions of challenges to the biocultural conservation of native maize}

\subsubsection{Perceptions of challenges by community context}

In Tutla, where traditional maize farming is still strongly rooted, most participants did not feel that native maize is at high risk at present. However, all focus groups discussed challenges that could potentially threaten native maize farming in the future. The prevailing concerns were related to a change in values around native maize and traditional farming. The participants referred to one of the main challenges as 'farmers' laziness', where farmers pursue the greatest profit with the least possible workload. This typically involves a switch from traditional farming practices to a modern way of farming using agrochemicals and technical tools to decrease the workload. However, this approach also decreases the diversity of the plants grown since traditional farming adopts a multi-cropping system

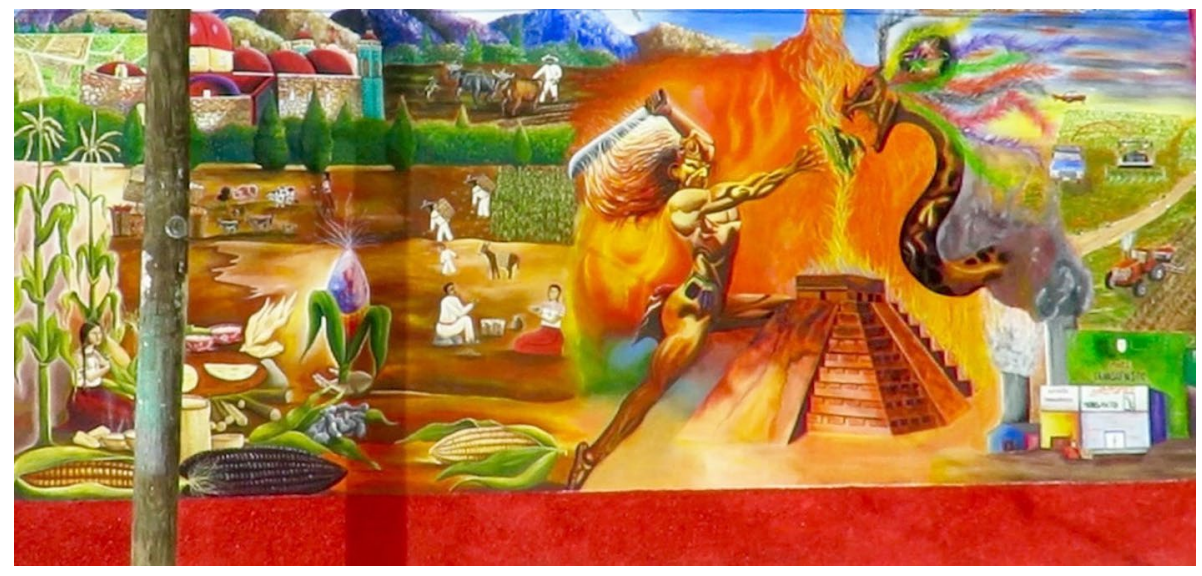

Fig. 3 Mural painted by Arturo Hernández Santiago (22 years, Zapotec) in collaboration with other six teenagers (14-20 years). 'Maize is life, without it we cannot do or be anything. We are now in a war and we have to defend native maize from transgenic corn and industry' (Quote from focus group discussions about the mural) 


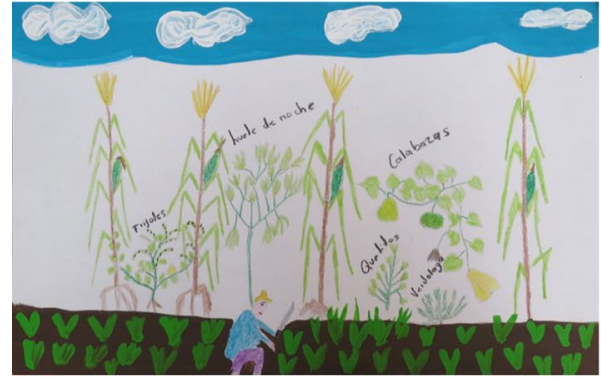

Old days

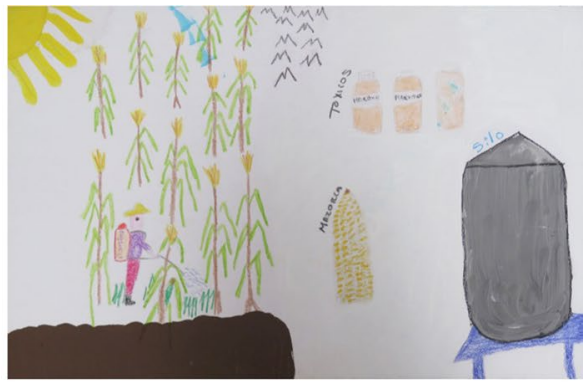

Present days

Fig. 4 Drawings by Angela Francisco Gallardo (59 years, Mixe). 'When the land was cleared with a machete, we could get pumpkins, string beans, purslane, quelite, nightshade, but now with the use of agrochemicals, all of this is finished' (Quote from focus group discussions about the drawings)

(Fig. 4). Another important (and related) concern raised by participants in this community was the substitution of maize farming by livestock grazing. They identified the higher profitability and lower drudgery of livestock farming as a challenge for keeping the interest in traditional maize farming alive. The amount of cleared land needed for livestock is high and brings up another challenge to native maize conservation-i.e. the reduction of the land available for planting native maize. In addition, as livestock farming requires deforestation, this reduces the food available for wild animals that may then use native maize as an alternative food source, resulting in greater financial losses for the farmers and a reduced desire to persist with this form of farming.

In contrast to Tutla where it was seen as more of an issue for the future, participants from Apostol expressed that native maize biodiversity in their community is under threat from various challenges right now. In Apostol, the cultural value and prestige awarded to native maize and traditional farming as a profession has declined significantly in recent years. Participants explained how access to cities, higher levels of education and exposure to TV and the Internet have created new social standards that members of the community are now striving to meet. Since the amount of time, effort and cost of native maize farming is not compensated by the income received from it, the profit obtained from native maize farming as an activity is not considered sufficient to fulfil these new social standards. Native maize has historically been grown for private consumption, and although surplus can be sold at local markets or to other community members, participants highlighted how people can now obtain food by other means than subsistence farming. For example, they can be employed in the cities, earning a higher income than native maize farming allows, and then buy maize (or other kinds of food) without the need to work long hard days on the farm. They can also migrate to the USA and earn dollars to buy the types of things they see 'successful' people on TV owning. Migrants can also support relatives by sending money to them. This ability to obtain food from outside sources and the need for more income to pursue alternative standards of living poses a significant challenge to the ongoing cultivation of native maize as a way to conserve its biodiversity in situ.

Another challenge that was raised by the participants, and which relates to the engagement in paid labour and migration, was the abandonment of the land. As members leave the community to pursue paid work, few people are left to farm the land. Moreover, there is a disruption in the transfer of knowledge and communication of the value of maize farming to the next generation. This situation (in addition to the new social standards) was 
described as having provoked a loss of knowledge and a lack of interest in native maize farming among young people (Fig. 5). Consequently, changes in values, modernity and migration were all key challenges identified by Apostol participants.

Both communities had previously been informed about the presence of transgene flow in Oaxaca (first documented by Quist and Chapela 2001), and they identified transgene flow as an important risk to native maize conservation (Agapito-Tenfen et al. 2017). However, when challenges were prioritized, transgenic corn was not one of the most important challenges to native maize conservation from the perspective of the participants.

\subsubsection{Perceptions of challenges by age}

We found common factors being emphasized by the same age groups in both communities. Elders in both communities emphasized the loss of knowledge and language as one of the most important challenges facing the conservation of maize biodiversity. The other age groups mentioned loss of knowledge and language as important, but did not prioritize this challenge. In contrast, elders did not consider low profitability to be as important as the other age categories. According to the older participants, the main challenge is the change of values that makes the next generation focus on profit rather than culture and tradition. They felt that native maize diversity could soon be lost because almost no young people showed any interest in it. Elders in both communities also mentioned that youth is not aware of the importance of a stable food source and the danger of losing native maize because they have access to food in markets. Particularly in Apostol, elders said that the young people had not suffered hunger as they did in the past, so they do not imagine the possibility of suffering hunger anymore (a significant original driver for maintaining subsistence native maize farming and for cultivating and developing different varieties).

As a group of participants, adults were more worried about the low profitability of native maize and suggested that if native maize could receive an increased price on the market, this would create more opportunities and incentives to continue native maize

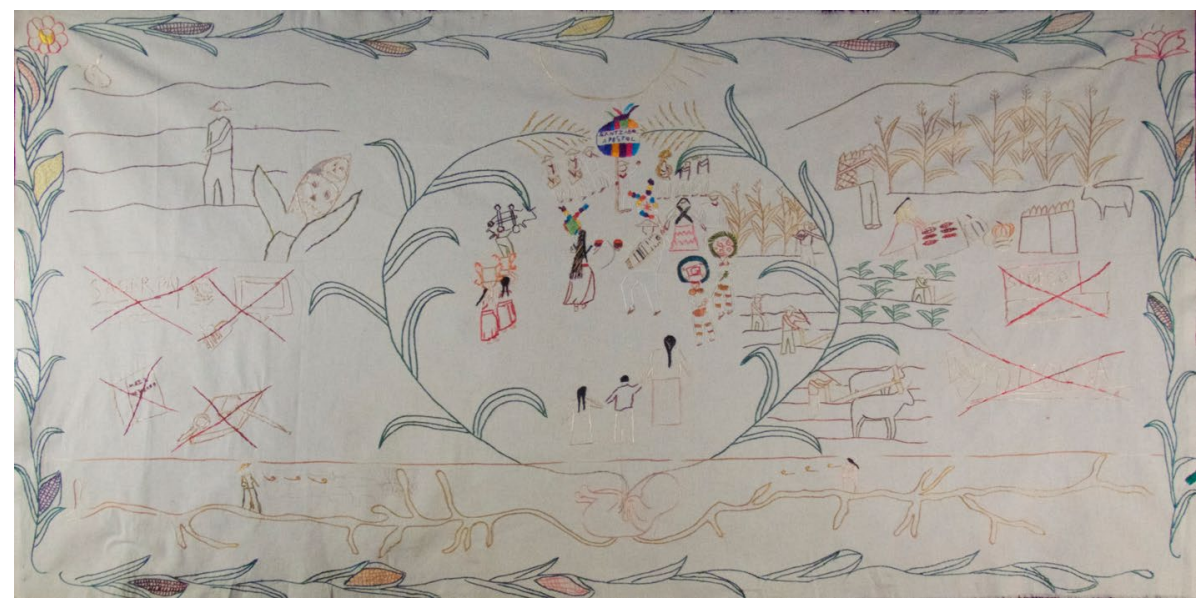

Fig. 5 Embroidery by Ana Sofía Ruíz Jerónimo (22 years, Zapotec). 'We are like a maize plant, and the knowledge of our ancestors our roots' (Quote from focus group discussions about the embroidery) 
farming. For them, the low profitability and the hard work that native maize farming entails were the main challenge and driver for people leaving native maize farming.

The youth across both communities put particular weight on the lack of interest in maize farming among their peers and the lack of maintenance of cultural and culinary traditions. They highlighted the social pressure they receive due to the establishment of the new social standards (i.e. the pressure to have a big house, a car, smartphones, etc.) and how native maize farming was not seen as a good means for fulfilling these needs. In addition, youth expressed that their parents and grandparents pushed them away from farming, encouraging them to 'go to school and pursue a career' rather than 'ending up a poor farmer like them'. Therefore, the lack of interest in farming that both the older and younger generations identified as a significant challenge to native maize conservation has different interpretations from each of the age groups in terms of its underlying causes, with each generation effectively placing some blame on the other. It is also interesting to note that the youth identified some challenges that the other age categories did not, particularly related to new knowledge, technologies and phenomena that were not built on the type of practical experiences that the elders and adults relied more upon. For example, youth mentioned genetically modified seeds as an important challenge, as well as the influence of industrial agriculture on climate change.

\subsubsection{Perceptions of challenges by gender}

Women across both communities demonstrated a particular concern about the culinary changes and health impacts brought about by a loss of native maize farming. They emphasized how throughout their history, the flavour of native maize had been extremely valued and tortillas with other kinds of maize were not accepted. However, it is now easier and more acceptable to buy rather than make tortillas, even though the taste is different and they are not considered to be as filling. It was also highlighted how it used to be a tradition to eat native maize, beans and the different herbs that were cultivated along with native maize in the field. Today, however, many prefer to eat meat or junk food when it is accessible rather than choose traditional food that may be more nutritious and healthier.

In contrast, men across both communities had a much stronger tendency to identify challenges related to migration, markets and changing values from a specifically agronomic point of view, i.e. highlighting the loss of knowledge about how to predict the best time to sow, the way to prepare the land, the importance of treating corn with respect for a better harvest, etc. They also placed more weight than women on profitability and balancing the amount of effort put into maize farming against the economic benefit obtained.

\subsection{Conservation strategies identified across the community/age/gender groups}

Differences across community context, age and gender were also manifest in the conception of the potential strategies for addressing the identified challenges and supporting native maize conservation. It is important to highlight that some desirable options such as to obtain a better national market price for native maize were mentioned in both communities. However, as a first step we chose to focus on exploring strategies that could be implemented by participants and community members themselves, which may eventually inspire other communities to take actions for conserving maize, or evoke attention from decision makers and investors. 
In Tutla, since the participants did not have the sense that their native maize was currently under threat, the solutions envisaged were more focused on how to improve their native maize practices and avoid the loss of knowledge and value in the future. The proposals for conservation strategies were then based on agronomic and technical aspects, such as to (a) perform workshops to inform members of the community about the risks of using agrochemicals, (b) explore alternatives for decreasing the workload while avoiding the use of herbicides, (c) try to always dedicate a piece of land to maize farming in addition to livestock grazing and (d) make children learn and value the traditional way of maize farming.

In contrast, in Apostol where they felt native maize was currently under threat and traditional farming was relegated only to elders, the solutions were more focused on: (a) recovering traditional knowledge, value and pride in native maize farming, (b) highlighting the role of native maize in their cultural identity and (c) strengthening the links between culture and maize. Accordingly, the strategies chosen in this community included transferring knowledge from elders to youth through the use of experimental plots at the school and to develop activities to promote an increased recognition of the value of and pride in maize farming. Interestingly, youth and elders agreed on these potential strategies as the elders wanted to transfer their knowledge and assure its permanence within the communities and the youth wanted to receive the knowledge and also share it with younger children. Sadly, elder women in Apostol expressed a loss of hope and actually could not give any proposal as a strategy to address the threats they identified since they did not believe that any strategy could make young people return to maize farming. However, they were enthusiastic to participate and help implement the strategies identified by others through the process. Adults men, conversely, proposed some more practical solutions to native maize conservation over a short-term period, such as to avoid buying seeds other than native varieties or continuing native farming. Adult women proposed also practical solutions but more related to traditional food and health practices, such as to keep cooking traditional foods for their taste and nutritious value.

Women of all ages in both communities were more focused than men on strategies that involved raising awareness so as to sustain native maize farming over the long term. They wanted, for example, to inform the community about the advantages and disadvantages of native maize and non-native seeds, to create and cultivate awareness of the value of native maize, to generate pride among youth in their indigenous and farming identity, to disregard social standards from TV and the Internet as they do not come from their communitarian needs and perspectives and to encourage children to participate with their parents in traditional maize farming and consequently maintain the knowledge over generations. Women were also more focused than men on keeping the culinary diversity linked to native maize alive and to disregard the new wave of junk foods and the increased consumption of meat. This means they also proposed raising awareness of the importance of having the type of diverse, nutritious and healthy foods that traditional maize farming provides. In contrast, men tended to propose solutions such as workshops to produce and use their own fertilizers, transfer of theoretical and practical knowledge in schools, always dedicating part of the land to native maize farming, etc. For a summary of the differences across groups and the types of challenges identified, see Table 2 and Figs. 6 and 7. 
Table 2 Key for the different categories of identified challenges to native maize conservation (abbreviations are given for the identified challenges for use in summary form in Figs. 5, 6)

\begin{tabular}{|c|c|}
\hline Challenges categories & Description \\
\hline Change of values & $\begin{array}{l}\text { This category represents changes in perceptions and values around native } \\
\text { maize farming. It includes } \\
\text { (a) A decrease in the value placed on native maize (DV) } \\
\text { (b) A lack of interest in native maize farming (LI), often because of a } \\
\text { (c) Change in focus towards monetary profits (MP) and } \\
\text { (d) The needs that arise with a cash economy and increasing social } \\
\text { standards (SS) which can no longer be fulfilled by just native maize } \\
\text { farming. This also connects to what participants called 'laziness' (LZ) } \\
\text { where farmers choose other livelihoods because of the hard work of } \\
\text { maize farming }\end{array}$ \\
\hline Farming practices & $\begin{array}{l}\text { This category refers to a switch from traditional to modern farming } \\
\text { practices, as indicated by the use of agrochemicals (AC), chainsaws } \\
\text { (CS) and/or tractors (TR) }\end{array}$ \\
\hline Agricultural substitution & $\begin{array}{l}\text { This category refers to the way native maize farming can be substituted } \\
\text { by other types of maize seeds such as hybrids (HS), by other crops like } \\
\text { flowers (OC) or by livestock (LS) }\end{array}$ \\
\hline Modernity & $\begin{array}{l}\text { The focus here is on societal change associated with modernity, such as } \\
\text { that resulting from easier access to cities (AC), access to higher educa- } \\
\text { tion (HE) and to the information now available by internet (IN) and } \\
\text { television (TV) }\end{array}$ \\
\hline Dietary changes & $\begin{array}{l}\text { This category captures the way people have changed their food prefer- } \\
\text { ences and diets. Including how it has become more normal to buy non- } \\
\text { native maize tortillas (NT), to eat more meat (MM) and to consume } \\
\text { junk foods such as pizza and hamburgers (JF) }\end{array}$ \\
\hline Loss of knowledge and language & $\begin{array}{l}\text { This category refers to both the loss of traditional knowledge associated } \\
\text { with native maize farming (LK) and a decline in the use of indigenous } \\
\text { language (LL) }\end{array}$ \\
\hline Migration & $\begin{array}{l}\text { This category captures challenges from the abandonment of farms (AF), } \\
\text { disruption in the transfer of knowledge from emigration (KT) and } \\
\text { return immigration introducing new ideas to the community (RI) }\end{array}$ \\
\hline Climate change & $\begin{array}{l}\text { Climate change is a category that includes challenges such as the wet } \\
\text { season being difficult to predict (DP) and unexpected droughts (DG) } \\
\text { that both affect yields }\end{array}$ \\
\hline Damage from wildlife & $\begin{array}{l}\text { This challenge refers to how deforestation is driving different animals to } \\
\text { eat a part of the native maize harvest, resulting in financial losses for } \\
\text { the farmers }\end{array}$ \\
\hline Low profitability & $\begin{array}{l}\text { This category refers to the way that the investment of money and labour } \\
\text { in native maize farming are disproportionally high compared with the } \\
\text { financial profit gained from selling the harvest (LP) }\end{array}$ \\
\hline Government programs & $\begin{array}{l}\text { This category represents the way economic subsidies from govern } \\
\text { programs can create dependencies and promote laziness as they offer } \\
\text { incentives not connected to native maize farming }\end{array}$ \\
\hline
\end{tabular}

\section{Discussion}

Our study adopted a biocultural approach to conservation. This approach recognizes that there is a high degree of interconnection between culture and biodiversity (Posey 1999). As stated by Bennett (2016), perceptions of conservation can differ among individuals in 


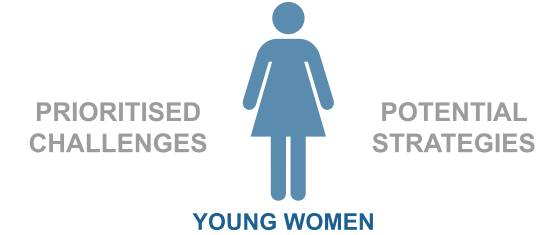

1. Change of values (LZ, LI, DV)

2. Agricultural substitution (SD, LS)

3. Farming practices (AC)

4. Dietary changes

5. Damage from wildlife

- Teach children the traditional ways of maize farming. Highof valuing and respecting native maize, and of caring and cherishing the lighting the importance diversity of maize and traditional knowledge and traditions.

- To allow land to be rested after being used for livestock and then using it for maize farming.

\section{ADULT WOMEN}

1. Agricultural substitution (LS)

2. Farming practices

3. Change of values (LZ, DV, MF)

4. Low profitability

5. Climate change (HP, LY)

- Force our sons to farm native maize and not lose the traditions.

- Designate land for maize farming in addition to livestock grazing.

- Care for our native maize; avoid the use of new seeds and potential contaminants.

\section{ELDER WOMEN}

1. Change of values (LZ, LI, MF)

2. Farming practices (AC)

3. Agricultural substitution (LS)

4. Loss of knowledge and language

5. Dietary changes
- Select and maintain our native seeds through generations as our ancestors did and encourage children to keep this tradition.

- Show new generations the traditional ways of maize farming without using agrochemicals.

\section{PRIORITISED
CHALLENGES \\ YOUNG MEN}

1. Change of values (LZ, LI, MF)

2. Low profitability

3. Agricultural substitution (SD, LS)

4. Farming practices (AC)

5. Damage from wildlife

. Ask

- Ask maize retailers to increase the price of native maize.

- Perform workshops with school students and parents to teach the importance of native maize farming for their Mexican identity.

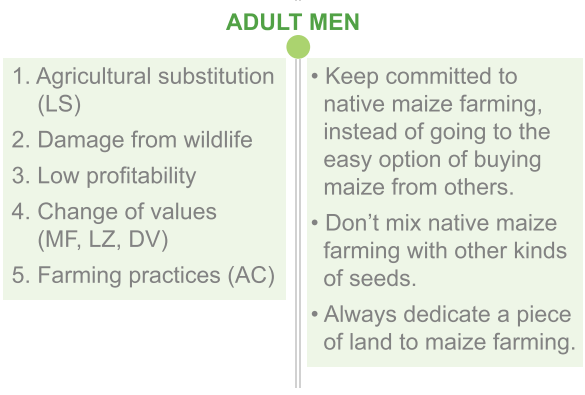

\section{ELDER MEN}

1. Change of values (LZ, LI, DV, MF)

2. Loss of knowledge and language

3. Farming practices (AC)

4. Agricultural substitution (LS)

5. Modernity (HS, AC)
- Raise awareness in parents and children about the importance of learning about traditional maize farming. Promote the value of maize and the will to care and cherish native maize and the land.

\section{COMMON PRIORITISED CHALLENGES}

\section{COMMON PRIORITISED STRATEGIES}

1. Change of values ( $L Z, L I, M F)$

2. Agricultural substitution (LS)

3. Farming practices (AC)

- Continue farming native maize and encourage children to learn from their parents in the plot.

- Promote the value of native maize farming over livestock and money.

Fig. 6 Prioritized challenges and potential conservation strategies as agreed by participants of Tutla. The key for the meaning of the initials in this figure is provided in Table 2 


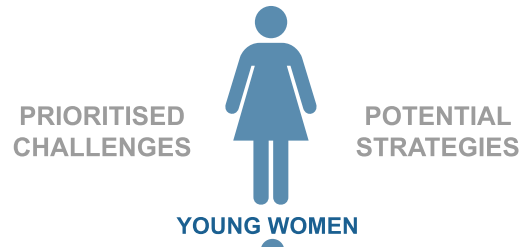

\begin{tabular}{l||l}
$\begin{array}{l}\text { 1. Change of values } \\
\text { (LI, SS) }\end{array}$ & $\begin{array}{l}\text { Encourage pride in } \\
\text { farmer indigenous }\end{array}$ \\
2. Modernity (IN, TV) & $\begin{array}{l}\text { identity, disregarding } \\
\text { social standards set by } \\
\text { 3. Low profitability }\end{array}$ \\
$\begin{array}{ll}\text { 4. Agricultural substitution the Internet. } \\
\text { (SD) }\end{array}$ & $\begin{array}{l}\text { Inform people about the } \\
\text { advantages and } \\
\text { 5. Migration (AF, KT, RI) }\end{array}$ \\
$\begin{array}{l}\text { disadvantages of using } \\
\text { other maize seeds } \\
\text { rather than native. } \\
\text { - Incentivize local } \\
\text { consumption of native } \\
\text { maize. }\end{array}$
\end{tabular}

\section{ADULT WOMEN}

1. Change of values
(LI, LZ, DV)
2. Farming practices
(AC, TR)
3. Modernity (IN, TV, AC)
4. Low profitability
5. Migration (AF, KT, RI)

- Promote the value of native maize farming among youth, by collecting knowledge from their parents on the land after school.

- Maintain native maize farming.

- Ask the government to incentivize native maize farming and consumption.

\section{ELDER WOMEN}

1. Change of values (LI, LZ, DV)

2. Farming practices (TR, AC)

3. Low profitability

4. Migration (AF, KT, RI)

5. Climate change (DG, HP)
- There are not many things that can be done. We cannot make rain. We don't have enough yields and profits from native maize. People migrate and abandon the land, diminishing the possibility of having more native maize produced.

\section{PRIORITISED
CHALLENGES \\ YOUNG MEN}

1. Change of values (LZ, LI, DV, SS)

2. Farming practices (AC, TR)

3. GM maize

4. Loss of knowledge and language

5. Climate change (HP)

- Avoid consuming and planting maize seeds other than native varieties.

- Make natural fertilizers instead of using agrochemicals.

- Educate children about the value of the land, maize and indigenous identity, in theory and practice.

\section{ADULT MEN}

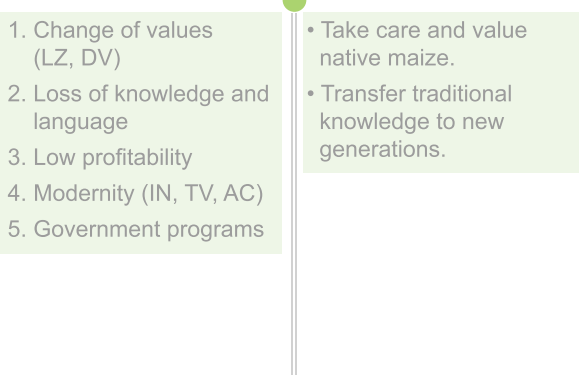

ELDER MEN

1. Farming practices (TR, AC)

2. Change of values (LZ, MF, LI, CU)

3. Migration (AF, KT, RI)

4. Agricultural substitution (SD, OC)

5. Loss of knowledge and language
- Use natural fertilizers and compost and farm the land manually.

- Be aware that seeds that migrants bring are not as good and resistant as native maize.

- Be informed and value native maize characteristics.

\section{COMMON PRIORITISED CHALLENGES}

1. Change of values (LI, MF, SS, CU)

2. Farming practices (AC)

3. Loss of knowledge and language

\section{COMMON PRIORITISED STRATEGIES}

- Transfer the knowledge from elders to youth and children.

- Encourage awareness of the value of native maize, traditions, indigenous language and identity.

Fig. 7 Prioritized challenges and potential conservation strategies as agreed by participants of Apostol. The key for the meaning of the initials in this figure is provided in Table 2 
accordance with their own values, socio-economic situation, culture and ethnicity, beliefs, experiences, etc. Our study underscores how contextual factors such as the socio-economic changes that arise from a lack of governmental support, international policies, globalization, out-migration and cultural exchange can shape the perceptions and motivation for native maize biocultural conservation. While internationally recognized ecological threats such as climate change and transgene flow were viewed as challenges to native maize, our participants specifically identified the changes in cultural values stemming from global processes and pressures as the priority challenge for conserving native maize.

Our discussion revolves around the heterogeneous perspectives relating to gender, age and communities on native maize conservation and the prospects of bridging different views and developing shared strategies for action. Furthermore, we would like to emphasize the value of performing art-based participatory research in a stepwise fashion for achieving this in a creative, equitable and inclusive manner. Being able to bridge heterogeneous perspectives through a participatory process that can give communities, a sense of ownership over the problem and agency over the solutions is essential for achieving effective biocultural conservation and positive change regarding agrobiodiversity.

\subsection{The significance of perspectives across different community contexts for native maize conservation}

Factors such as ethnicity (Brush and Perales 2007; Orozco-Ramírez et al. 2016) can explain some of the differences between the two communities in our study. The Mixe people of Tutla call themselves the never-conquered people and are historically considered to be one of the most vigorous indigenous people in Oaxaca due to their strong community ties, cultural pride and their struggle to defend their indigenous autonomy (Blanco 2012; Rousseau and Hudon 2017). In Tutla, the land is under a collective property regime and is managed by a communitarian assembly that is highly respected within the community. All external proposals have to be discussed and decided by communitarian assembly, and these decisions then need to be upheld and abided to by all. For example, the Tutla community has rules preventing the use of maize seeds other than native varieties in this community. Although this was originally introduced to prevent the risk of transgene flow, this rule also facilitates the ongoing cultivation of native maize in the community and thereby reduces some of the challenges they experience.

In contrast, Apostol is populated by Zapotec people, who responded very differently to the Spanish colonization. Zapotec are great negotiators and adapted cultural traits from the Spanish as a strategy to survive the colonization. Therefore, they are known to adopt new technologies and cultural expressions external to the community more easily (Acosta Márquez 2007; Marcus and Flannery 1996). Easier access to higher education, a greater cultural exchange due to migration flow and exposure to TV and Internet were identified by participants as vectors for granting a lower cultural value and prestige of farming native maize in Apostol and the community's openness to these may be connected to their cultural history and identity.

Despite the differences linked to ethnicity in this study, we believe there is no strong basis to claim that the different perceptions collected can be explained primarily by ethnicity. External influences that differ among communities, such as agriculture policies and trade agreements resulting in bankruptcy (CONEVAL 2016; Eakin et al. 2015; Sweeney et al. 2013), migration, TV and Internet fostering cultural changes (Robson and Berkes 2011b) and substitution of maize farming by other sources of livelihood (Galvan-Miyoshi 
et al. 2015), are all important factors currently affecting the conservation of crop biodiversity.

Although participants in Tutla and Apostol identified similar challenges (such as the change in value granted to native maize farming), the degree of threat was perceived differently and this affects the level of motivation to take action. This is because the feeling of threat can ignite the motivation to improve the current situation, in our case towards an effective conservation of native maize biodiversity. As we stated previously, in Tutla participants did not feel that native maize is currently under threat. Thus, even though participants were not indifferent to the potential challenges facing native maize biodiversity conservation, they did not express the need to recover something lost or a strong will to act immediately. In contrast, Apostol participants explained that native maize was presently at risk in their community and recognized a need to act immediately. This included developing conservation actions and strategies directed towards recovering and transferring traditional knowledge, value and pride in native maize farming, language, traditions and identity. Different communities therefore not only face different levels of threat to native maize conservation depending on their cultural context, they also have different levels of motivation to take action.

\subsection{The significance of perspectives across different ages for native maize conservation}

Robson et al. (2017) have explained how out-migration accelerates modernity and globalization and changes the values of younger generations. The Internet has also opened new possibilities, particularly for younger generations to collect experiences, ideas and values from beyond their communities. These changes appear to have influenced the level of interest among the younger generations for practicing native maize farming (Bjarnason and Thorlindsson 2006). In addition, though, it is important to recognize that historically, indigenous people have suffered discrimination all over the world and been told through education and policies that their language, culture, food and traditional farming practices are not of great value (Wilson and Bird 2005). All of these pressures and challenging values were identified by our participants. Young participants from both communities (although more strongly articulated in Apostol) highlighted the strong social pressure they felt (including from their families) to pursue scholarships for their education and to practice other activities and careers than native maize farming. However, most of the young participants indicated that they did in fact value and would like to reinforce, continue and promote the knowledge and culture attached to native maize farming despite all of those pressures. This is because native maize farming not only brought them good family memories but was also deeply connected to their cultural identity and pride. Learning this created hope for the older participants that the youth were actually willing to actively contribute in the conservation of native maize and their culture if they were given the chance and opportunity. Overcoming the perception that no young people have an interest in farming or traditional culture opens opportunities to develop new strategies for native maize conservation and provides hope for the continuation of traditional farming more generally.

As described previously, adult concerns were more focused on the hard work needed for native maize farming and the lack of profitability of the activity. This relates to what elders called laziness. However, when this 'laziness' was seen from the perspective of the adults who were being accused of it, it became clear that actually many adults pursue alternative economic activities in addition to native maize farming to supplement their livelihood 
and achieve new standards of living for their families. This includes part time jobs in the nearby cities, or a combination of livestock and native maize farming, and/or art/craft making. This means that although they may be committed to the value of native maize farming, they are also busy pursuing other more profitable activities in addition to farming to try and meet accelerating global standards of living. This contrasts with the reality of elders who were able to primarily dedicate their time to working in the fields. This means that what one generation perceives as laziness is experienced by another generation as trying to save time to pursue other economic activities. Hearing these different interpretations of the situation and understanding the divergence in the lived realities of the participants from different age groups is important for building a more holistic picture of the challenges facing native maize farming and creating an improved intergenerational understanding.

\subsection{The significance of perspectives across different genders for native maize conservation}

Traditional culinary uses and religious values have previously been identified as factors of influence in the conservation of crop biodiversity (Littaye 2016). However, our study supports other work (Bhattarai et al. 2015) suggesting that challenges and potential strategies related to these factors are gender weighted. Participants in our study conveyed that the choice of whether to continue native maize farming or not and the selection of variety for planting was a family discussion. However, the different genders had different emphases and power in these discussions. The decision of whether to continue maize farming at all often relies mostly on the men, who in doing so will assess questions of its ability to provide a sufficient livelihood. However, when the choice to continue is made, the selection of what variety to farm is more influenced by women. Women can have a strong say over the type of seeds to be planted, which they will often argue for on the basis of culinary uses such as taste, ease of cooking and health considerations. However, in considering seed choice, men will predominantly tend to think about agronomic aspects such as water consumption, life cycle, yield, adaptation to climate changes and market prices. Understanding the different criteria and types of decisions that women and men have regarding native maize farming in these communities is significant if we are to be able to generate effective strategies for the conservation of native maize biodiversity.

Another difference in perspectives between the genders that is significant is the way male participants tended to look upon the more immediate challenges of their livelihood such as access to profitable markets and time investments, whereas women focused on future generations and native maize as quality food, health and traditions in the community. These differences mean that the strategies for conservation will vary significantly between men and women, e.g. in terms of focusing on the short versus the long term and emphasizing economic versus value-based approaches. It is therefore crucial that these differences are understood and negotiated towards common solutions.

\subsection{Bridging heterogeneous perspectives to arrive at shared strategies}

Uncovering the heterogeneity of perspectives within the community and then working to discuss and reconcile these differences allowed for the creation of shared strategies for action. In this work, we focused on developing shared strategies for actions that communities could enact themselves, with their own efforts, and that were possible to realize to bring positive change in the near future. This was so as to empower communities to see 
the actions they were able to take to improve the situation without necessarily relying on the actions of other actors. Priority challenges such as attaining a fair market price for native maize cannot be overcome without political or governmental support, and for this study, we chose to focus on those strategies that the communities themselves could take direct action on to make a difference. This does not negate the importance of cooperative arrangements involving collaborative action with other organizations or governments, and these types of actions were just not the focus in this particular study. Extending the work to include more collaborative actions with actors beyond the local community would, however, be relevant for further action-based research. Shared strategies such as holding festivals to honour native maize, as proposed and pursued by Apostol participants, can satisfy multiple demands. Festivals are a traditional means used in Oaxaca to strengthen community cohesiveness and reinforce cultural identity. Such festivals can help with the transfer of knowledge between generations (as desired by youth) and increase the pride in and respect for native maize farming (as desired by elders). Showing the diversity of plates and products, it is possible to make with native maize at such a festival can also promote a healthier diet (as desired by women) and increase consumer demand for native maize (as desired by men). Such festivals could also be scaled up from the local to the national level to honour and celebrate the importance of biodiversity and the important global role farmers play in keeping this alive.

Another shared strategy developed by participants was to have schools and churches establish community gardens and agricultural plots. These could be intergenerational initiatives to teach farming practices, which would enable knowledge transfer and avoid the loss of traditional knowledge. Another educational strategy, proposed and pursued by participants in Tutla, was to hold workshops on agroecological methods. This was proposed as a way to counter the push towards modern industrialized agricultural models, to support the ongoing development of traditional farming methods as more environmentally and socially friendly forms of modern agriculture. Such local educational strategies could also be upscaled to promote the value of traditional farming, increase the pride connected to being an indigenous farmer and build respect and gratitude from non-indigenous society for the important work farmers perform. Such upscaling is crucial to encourage future generations to keep native maize farming alive without feeling like lower-class citizens. Each of these proposals developed by the participants demonstrates the possibility to integrate heterogeneous perspectives into shared strategies for action.

\subsection{The value of a participatory art-based method with a stepwise design}

In this study, we applied a participatory art-based research method with a stepwise design. Participatory methods have long been acknowledged as important for performing research that is community centred and inclusive rather than extractive, acknowledging participants' expertise and granting them ownership over the work (Reed 2008). By incorporating artbased approaches, we were also able to encourage new types of creative reflection and easily catalyse discussions (Coemans and Hannes 2017). By using a stepwise design in our participatory art-based method, we could first work with specific groups on their own to document heterogeneous perspectives and then bring them together to discuss these differences and work to build common understandings and shared strategies. This process was particularly productive for developing critical thinking, namely the ability of participants to reflect on the problem, understand their contribution, assume responsibility and recognize their own potential to act and be part of the solution. In our case, the participatory 
process and the self-reflections about the value of maize encouraged participants to look upon themselves as guardians of native maize. This was particularly evident in Apostol, where participants decided to form a group to take action and called themselves the "warriors of maize' (Rivera Lopez et al. 2018).

Through the work of this study, we have aimed to contribute empirical knowledge to the increasing literature supporting biocultural approaches to the conservation of agricultural biodiversity. We have highlighted the importance of exploring heterogeneous perspectives across different ages, genders and cultural contexts for developing an integrated understanding of the complexities of the problem and the value of using a stepwise design to create shared solutions. This work has demonstrated the importance of equitable inclusion of diverse perspectives in research for agrobiodiversity conservation and the possibility of reconciling differences into effective multifunctional strategies for positive change.

Acknowledgements Funding was provided by Norges Forskningsråd (Grant No. 236840).

\section{Compliance with ethical standards}

Conflict of interest The authors declare that they have no conflict of interest.

Open Access This article is licensed under a Creative Commons Attribution 4.0 International License, which permits use, sharing, adaptation, distribution and reproduction in any medium or format, as long as you give appropriate credit to the original author(s) and the source, provide a link to the Creative Commons licence, and indicate if changes were made. The images or other third party material in this article are included in the article's Creative Commons licence, unless indicated otherwise in a credit line to the material. If material is not included in the article's Creative Commons licence and your intended use is not permitted by statutory regulation or exceeds the permitted use, you will need to obtain permission directly from the copyright holder. To view a copy of this licence, visit http://creativecommons.org/licenses/by/4.0/.

\section{References}

Acosta Márquez, E. (2007). Zapotecos del Istmo de Tehuantepec: Pueblos indígenas del México contemporáneo Comisión Nacional para el Desarrollo de los Pueblos Indígenas, México.

Agapito-Tenfen, S., Lopez, F. R., Mallah, N., Abou-Slemayne, G., Trtikova, M., Nodari, R. O., et al. (2017). Transgene flow in Mexican maize revisited: Socio-biological analysis across two contrasting farmer communities and seed management systems. Ecology and Evolution, 7(22), 9461-9472.

Appendini, K. (2014). Reconstructing the maize market in rural Mexico. Journal of Agrarian Change, 14, 1-25. https://doi.org/10.1111/joac.12013.

Appendini, K., \& Liverman, D. (1994). Agricultural policy, climate change and food security in Mexico. Food Policy, 19, 149-164.

Appendini, K., \& Quijada, M. G. (2016). Consumption strategies in Mexican rural households: Pursuing food security with quality. Agriculture and Human Values, 33, 439-454.

Aragón-Cuevas, F., Taba, S., Hernández, J., Figueroa, J., \& Serrano, V. (2006). Actualización de la información sobre los maíces criollos de Oaxaca. Instituto Nacional de Investigaciones Forestales Agrícolas y Pecuarias, Informe final SNIB-CONABIO proyecto No CS002 México, DF.

Barrera-Bassols, N., Astier, M., Orozco, Q., \& Boege, E. (2009). Saberes locales y defensa de la agrobiodiversidad: Maíces nativos vs. maíces transgénicos en México. Papeles, 107, 77-91.

Becerril, J., \& Abdulai, A. (2010). The impact of improved maize varieties on poverty in Mexico: A propensity score-matching approach. World Development, 38, 1024-1035. https://doi.org/10.1016/j.world dev.2009.11.017.

Bee, B. A. (2014). "Si no comemos tortilla, no vivimos:" Women, climate change, and food security in central Mexico. Agriculture and Human Values, 31, 607-620.

Bennett, N. J. (2016). Using perceptions as evidence to improve conservation and environmental management. Conservation Biology, 30, 582-592. 
Berkes, F. (2009). Indigenous ways of knowing and the study of environmental change. Journal of the Royal Society of New Zealand, 39(4), 151-156. https://doi.org/10.1080/03014220909510568.

Bezner Kerr, R. (2013). Seed struggles and food sovereignty in northern Malawi. Journal of Peasant Studies, 40, 867-897.

Bhattarai, B., Beilin, R., \& Ford, R. (2015). Gender, agrobiodiversity, and climate change: A study of adaptation practices in the Nepal Himalayas. World Development, 70, 122-132. https://doi.org/10.1016/j. worlddev.2015.01.003.

Bjarnason, T., \& Thorlindsson, T. (2006). Should I stay or should I go? Migration expectations among youth in Icelandic fishing and farming communities. Journal of Rural Studies, 22, 290-300.

Blanco, I. I. (2012). Autonomía comunitaria y caciquismo: identidad étnica, control social y violencia en una comunidad mixe de Oaxaca. Institut Català Internacional per la Pau.

Boege, E., \& Chan, G. V. (2008). El patrimonio biocultural de los pueblos indígenas de México: Hacia la conservación in situ de la biodiversidad y agrodiversidad en los territorios indígenas. Instituto Nacional de Antropología e Historia

Bonneuil, C., Foyer, J., \& Wynne, B. (2014). Genetic fallout in bio-cultural landscapes: Molecular imperialism and the cultural politics of (not) seeing transgenes in Mexico. Social Studies of Science, 44(6), 901-929.

Bordi, I. V., Ortiz, H. T., \& Linares, C. D. H. (2016). Miradas al futuro: El relevo generacional en el desarrollo de la conciencia social como estrategia de conservación de los maíces nativos. Carta Económica Regional, 115, 20.

Brush, S. B., \& Perales, H. R. (2007). A maize landscape: Ethnicity and agro-biodiversity in Chiapas Mexico. Agriculture Ecosystems \& Environment, 121, 211-221.

Carlson, E. D., Engebretson, J., \& Chamberlain, R. M. (2006). Photovoice as a social process of critical consciousness. Qualitative Health Research, 16, 836-852. https://doi.org/10.1177/1049732306 287525 .

Carruthers, D. V. (2001). The politics and ecology of indigenous folk art in Mexico. Human Organization, 60, 356-366. https://doi.org/10.17730/humo.60.4.9xmv7dd0brc6kf8e.

Coemans, S., \& Hannes, K. (2017). Researchers under the spell of the arts: Two decades of using artsbased methods in community-based inquiry with vulnerable populations. Educational Research Review, 22, 34-49. https://doi.org/10.1016/j.edurev.2017.08.003.

CONEVAL. (2016). Medicion de la Pobreza 2008-2016. Accessed April 2019.

Davidson-Hunt, I. J., et al. (2012). Biocultural design: a new conceptual framework for sustainable development in rural indigenous and local communities. SAPI EN S Surveys and Perspectives Integrating Environment and Society, 5, 33-45.

De Ita, A. (2007). Catorce años de TLCAN y la crisis de la tortilla. Programa de las Américas. Reporte Especial. Nov.

De La Rosa, M. G., \& Schadl, S. M. (2014). Getting up for the people: The visual revolution of ASAROaxaca. Pm Press

De St. Maurice, G., \& Miller, T. L. (2017). Less palatable still valuable: Taste, crop agrobiodiversity, and culinary heritage. Food, Culture \& Society, 20, 193-200. https://doi.org/10.1080/15528 014.2017.1305824.

Dove, M. R., Smith, D. S., Campos, M. T., Mathews, A. S., Rademacher, A., Rhee, S., et al. (2009). Globalisation and the construction of western and non-western knowledge. Local science vs. global science: Approaches to indigenous knowledge in international development (pp. 129-154). Oxford: Berghahn Books.

Eakin, H., Appendini, K., Sweeney, S., \& Perales, H. (2015). Correlates of maize land and livelihood change among maize farming households in Mexico. World Development, 70, 78-91. https://doi. org/10.1016/j.worlddev.2014.12.012.

Fitting, E. (2011). The struggle for maize: Campesinos, workers, and transgenic corn in the Mexican countryside. Durham: Duke University Press.

Flicker, S., Travers, R., Guta, A., McDonald, S., \& Meagher, A. (2007). Ethical dilemmas in communitybased participatory research: Recommendations for institutional review boards. Journal of Urban Health: Bulletin of the New York Academy of Medicine, 84, 478-493. https://doi.org/10.1007/s1152 4-007-9165-7.

Freire, P. (1970). Pedagogy of the oppressed (p. 72). New York: Continuum.

Galvan-Miyoshi, Y., Walker, R., \& Warf, B. (2015). Land change regimes and the evolution of the maize-cattle complex in neoliberal Mexico. Land, 4, 754.

Gavin, M. C., McCarter, J., Mead, A., Berkes, F., Stepp, J. R., Peterson, D., et al. (2015). Defining biocultural approaches to conservation. Trends in Ecology \& Evolution, 30, 140-145. https://doi. org/10.1016/j.tree.2014.12.005. 
Graddy, T. G. (2013). Regarding biocultural heritage: In situ political ecology of agricultural biodiversity in the Peruvian Andes. Agriculture and Human Values, 30, 587-604. https://doi.org/10.1007/ s10460-013-9428-8.

Hellin, J., Bellon, M. R., \& Hearne, S. J. (2014). Maize landraces and adaptation to climate change in Mexico. Journal of Crop Improvement, 28, 484-501. https://doi.org/10.1080/15427528.2014.92180 0 .

Hoffmann, V., Probst, K., \& Christinck, A. (2007). Farmers and researchers: How can collaborative advantages be created in participatory research and technology development? Agriculture and Human Values, 24, 355-368. https://doi.org/10.1007/s10460-007-9072-2.

INEGI. (2011). XIII Censo de Población y Vivienda 2010. Accessed April 2019.

Kato Yamakake, T. Á., Sánchez Mapes, C., Mera Ovando, L. M., Serratos Hernández, J. A., \& Bye Bottler, R. A. (2009). Origen y diversificación del maíz: Una revisión analítica. Mexico: Universidad Nacional Autónoma de México.

Lau, J. D., \& Scales, I. R. (2016). Identity, subjectivity and natural resource use: How ethnicity, gender and class intersect to influence mangrove oyster harvesting in The Gambia. Geoforum, 69, 136146. https://doi.org/10.1016/j.geoforum.2016.01.002.

Lilja, N., \& Bellon, M. (2008). Some common questions about participatory research: A review of the literature. Development in Practice, 18, 479-488. https://doi.org/10.1080/09614520802181210.

Littaye, A. Z. (2016). The multifunctionality of heritage food: The example of pinole, a Mexican sweet. Geoforum, 76, 11-19. https://doi.org/10.1016/j.geoforum.2016.08.008.

Long, J. W., Ballard, H. L., Fisher, L. A., \& Belsky, J. M. (2016). Questions that won't go away in participatory research. Society \& Natural Resources, 29, 250-263.

López, Bárcenas F. (2016). Los movimientos indígenas en México: Rostros y caminos. El Cotidiano, $200,60-75$.

Marcus, J., \& Flannery, K. V. (1996). Zapotec civilization: How urban society evolved in Mexico's Oaxaca Valley. London: Thames and Hudson.

McCaughan, E. J. (2006). Notes on Mexican art, social movements, and Anzaldúa's "Conocimiento". Social Justice, 33, 153-164.

Mendez, V. E., Bacon, M. C., \& Roseann, C. (2013). Agroecology as a transdisciplinary, participatory, and action-oriented approach. Agroecology and Sustainable Food Systems, 37, 3-18.

Minkler, M. (2004). Ethical challenges for the "outside" researcher in community-based participatory research. Health Education \& Behavior, 31, 684-697.

Nadal, R., \& Wise, T. A. (2004). The environmental costs of agriculture trade liberalization: Mexico-US Maize Trade Under NAFTA. In Global Development and Environment Institute, Tufts University. Citeseer

Ordonez, M. d. J., \& Rodríguez, P. (2008). Oaxaca, el estado con mayor diversidad biológica y cultural en México, y sus productores rurales. Ciencias, 91(91), 54-64.

Orozco-Ramírez, Q., Ross-Ibarra, J., Santacruz-Varela, A., \& Brush, S. (2016). Maize diversity associated with social origin and environmental variation in Southern Mexico. Heredity, 116, 477.

Pérez-García, O., \& del Castillo, R. F. (2016). The decline of the itinerant milpa and the maintenance of traditional agrobiodiversity: Crops and weeds coexistence in a tropical cloud forest area in Oaxaca, Mexico. Agriculture, Ecosystems \& Environment, 228, 30-37.

Posey, D. A. (1999). Cultural and spiritual values of biodiversity. London: Intermediate Technology Publications.

Quist, D., \& Chapela, I. H. (2001). Transgenic DNA introgressed into traditional maize landraces in Oaxaca, Mexico. Nature, 414(6863), 541.

Reed, M. S. (2008). Stakeholder participation for environmental management: A literature review. Biological Conservation, 141, 2417-2431.

Rivera Lopez, F., Wickson, F., \& Hausner, V. H. (2018). Finding CreativeVoice: Applying arts-based research in the context of biodiversity conservation. Sustainability, 10(6), 1-18.

Robson, J., \& Berkes, F. (2011a). How does out-migration affect community institutions? A study of two indigenous municipalities in Oaxaca, Mexico. Human Ecology, 39, 179-190. https://doi. org/10.1007/s10745-010-9371-x.

Robson, J. P., \& Berkes, F. (2011b). Exploring some of the myths of land use change: Can rural to urban migration drive declines in biodiversity? Global Environmental Change, 21, 844-854. https://doi. org/10.1016/j.gloenvcha.2011.04.009.

Robson, J., Klooster, D., Worthen, H., \& Hernández-Díaz, J. (2017). Migration and agrarian transformation in Indigenous Mexico. Journal of Agrarian Change. https://doi.org/10.1111/joac.12224.

Rosset, P. M., Machín Sosa, B., Roque Jaime, A. M., \& Ávila Lozano, D. R. (2011). The Campesinoto-Campesino agroecology movement of ANAP in Cuba: Social process methodology in the 
construction of sustainable peasant agriculture and food sovereignty. The Journal of Peasant Studies, 38, 161-191.

Rousseau, S., \& Hudon, A. M. (2017). Indigenous self-determination: From national dialogues to local autonomies. In C. Ewig (Ed.), Indigenous women's movements in Latin America (pp. 85-110). Berlin: Springer.

Sweeney, S., Steigerwald, D. G., Davenport, F., \& Eakin, H. (2013). Mexican maize production: Evolving organizational and spatial structures since 1980. Applied Geography, 39, 78-92. https://doi. org/10.1016/j.apgeog.2012.12.005.

Swiderska, K., \& Argumedo, A. (2006). Hacia un enfoque holístico para la protección del conocimiento indígena: Las actividades de las UN, el "Patrimonio Bio-cultural Colectivo" y el FPCI-UN (pp. 1-15). New York.

Tuxill, J., Reyes, L. A., Moreno, L. L., Uicab, V. C., \& Jarvis, D. I. (2010). All maize is not equal: Maize variety choices and Mayan foodways in rural Yucatan, Mexico (pp. 467-486). https://doi. org/10.1007/978-1-4419-0471-3_19.

Wang, C., \& Burris, M. A. (1997). Photovoice: Concept, methodology, and use for participatory needs assessment. Health Education \& Behavior, 24, 369-387.

Whitford, M. (2008). Oaxaca's indigenous Guelaguetza festival: Not all that glistens is gold. Event Management, 12(3-4), 143-161.

Wilson, A. C., \& Bird, M. Y. (2005). For indigenous eyes only: A decolonization handbook. Santa Fe: School of American Research.

Publisher's Note Springer Nature remains neutral with regard to jurisdictional claims in published maps and institutional affiliations. 